\title{
Diasporic Blackness: The Life and Times of Arturo Alfonso Schomburg by Vanessa K. Valdés
}

\author{
Casarae L. Gibson • Syracuse University
}

New York: SUNY Press, 2017. 202 pages.\$20.95, Cloth. ISBN: 978-1-4384-6514-2

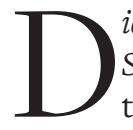
iasporic Blackness: The Life and Times of Arturo Alfonso Schomburg by Vanessa K. Valdés is an updated hise toriography of the known bibliophile's life placing special emphasis on Afro-latinx heritage in the Americas and global-sphere. A revered leader in black archivist studies, Schomburg's personal library collection of works by those of African descent, became the premise for what we now come to know as the Schomburg Center for Research in Black Culture. Valdés centers Schomburg's identity within a curator framework but moves beyond that to place his AfroLatino lineage at the fore. The book deals with the transnational experiences of Schomburg, his formative years in Puerto Rico and the Virgin Islands and his ascension to adult life in the United States, primarily New York City. What distinguishes Valdés' book from previous literature written about Schomburg, most notably Elinor Des Verney Sinnette's Arthur Alfonso Schomburg: Black Bibliophile and Collector published in 1989, is that Schomburg's legacy is the blueprint for cementing black excellence not only within the confines of U.S. native Black historiography, but to accentuate Afro-latinidad as part of the fabric of U.S. politics and culture. Schomburg was an elusive figure, often evading questions about his identity through body language in order to assimilate into U.S. black culture and across race and class lines. Valdés pays attention to Schomburg's ambiguous nature maintaining he and others "did not, then leave their Spanish-Caribbean communities behind; rather, they found acceptance and ease of living in already existing African diasporic spaces" (9). Such a statement ends the claim that Schomburg forgot about his Hispanic and island roots, rather it solidifies his accomplishment of forging cross-cultural connections between African communities in the Americas; staking claim in recovering artifacts and creating longstanding institutions that recognizes the contributions of a marginalized people.
Chapter 1: “'Patria y Libertad': Schomburg and Puerto Rico" examines his "intellectual genealogy" in addition to men and women such as Ramón Emeterio Betances, Eugenio María de Hostos, Lola Rodríguez de Tió, José Martí and Salvador Brau among others who influenced his recognizable attributes as a scholar and curator. Embedded in the chapter are overviews of each scholar and revolutionary mentioned above and how each shaped Schomburg's career and the advancement of Spanish-Caribbean liberation for people of African descent. The inclusion of luminaries continues the significance Valdés engages with her readers to make prevalent Afro-Latinx history and Schomburg's life as an entry point to learning such stories affirming all lives of African descent. Puerto Rico, the birthplace of Schomburg, serves as the backdrop to linking the geographical intersections of Puerto Rican and U.S. history, specifically "the struggle for equality with the colonizer that Liberals had begun under Spain would continue for decades with the new Mother Country [United States]" (52). These politics informed Schomburg's personal and professional life as the next chapter divulges into examining his life as leader and family man.

Chapter 2: "The Diasporic Race Man as Institution Builder" analyzes Schomburg's migration throughout the United States from the South to the North taking up the trade of race man and global humanitarian. Schomburg was a member of prestigious institutions for African Americans including the Prince Hall Masons, The Negro Society for Historical Research, The American Negro Academy, The National Association for the Advancement of Colored People (NAACP), and the National Urban League. Such organizations placed Schomburg in the upper middle-class of the black elite. Valdés reveals Schomburg's commitment to service and leadership as a method for uplifting the black race and utilizing education as a process by which liberation "for peoples of African descent" could be achieved (55). The chapter also details Schomburg's marriages to Elizabeth Morrow Taylor and Elizabeth Green until their deaths 
fathering five children who bear Spanish-speaking names. The naming of his children is significant because though they did not learn their father's native tongue, Schomburg's intentional designation of Spanish identity into his children's origins as Valdés points out, is his effort to bring attention to his Afro-Latinx heritage.

Chapter 3: "Afro-Latinx Chronicles: Schomburg's Writings" delves into his scholarship. Over the course of Schomburg's life, his speeches at historical black institutions and writings in prominent magazines such as the NAACP's The Crisis, added to his resume a foremost thinker in Africana life and studies. Valdés situates representations of Afro-Latinx culture and politics within a discussion about Schomburg's efforts to give claim to "narratives of the African diaspora" (71). In doing so, Valdés examines Schomburg's essays as crónicas, known as "short historical accounts that blend reporting with editoral content" which were "written in Spanish and Portuguese throughout the hemisphere" (72). Schomburg wrote short histories of Gabriel de la Concepción Valdés (known as Plácido) and General Evaristo Estenoz illustrating the sacrifice and contributions of Afro-Cuban artists and revolutionaries. The author concludes the chapter showcasing Schomburg's involvement in academic institutions and freemansory and contributing essays for such organizations as the Negro Society for Historical Research, the American Negro Academy, and the Prince Hall Masons. Similarly, Valdés includes the rise of the Harlem RenaissanceNew Negro Movement in the U.S. and Schomburg's influence writing his well-known "The Negro Digs Up His Past" as a point in anchoring Afro-Latinx and African Americans' history that devours any reference to white supremacist sentiments that have historically written off our heritage.

Chapter 4: “'Witness for the Future': Schomburg and His Archives" spotlights the man who labored for decades building an archive that today is recognized as the primary site for research of the African diaspora. Valdés' epigraph taken from "The Negro Digs Up His Past" where Schomburg makes plain the collection of African artifacts and literature at the New York Public Library in Harlem (now the Schomburg Center for Research in Black Culture) as proof of black excellence testifies to a history of African ancestry devoid of stereotypes and caricatures. Schomburg bears witness to the preservation of African archives; he became the first curator of the Division of Negro Literature, History, and Prints at the $135^{\text {th }}$ Street Branch Library in Harlem and the Negro Collection at the Library of Fisk University. The importance of this chapter is Valdés astute focus on HBCUs (Historically Black Colleges and Universities) as an interlocutor to disseminating Africana history. This information is integral because it locates Schomburg in the heart of the Jim Crow South and closely connects his identity to HBCUs mission of racial uplift and education. The chapter concludes with Schomburg's curation as an implicit framework for future generations to dive into the archives he once collected in his Brooklyn home. Moreover, as the final chapter uncovers, Schomburg himself was a living archive, breathing Africana history and forging new paths in understanding the diaspora.

Chapter 5: "Furtive as he Looks': The Visual Representation of Schomburg" discloses his successful attempts to elude his racial identity when he saw fit. Valdés includes portraits and photographs of Schomburg from age four to about fifty-two noting that his uninviting and performative detraction from the camera reveals an "uncomfortable" man that "often looks above the lens" (112). The author goes on to discuss the early formation of photography and locates Schomburg's stiff posture to avoid questions that the viewer's gaze might attempt to ask. One such asking is a portrait taken with his sister Lola who is of lighter skin and can pass for white. Another is Schomburg's immigration photo where he is directly looking into the camera with discomfort. In the portrait with Lola, Schomburg also looks at the camera, but his stare challenges viewers on the receiving end to say something about his and his sister's racialized identity. In both cases, and throughout the chapter, Valdés makes the case to examine Schomburg's photop graphs as readings to understand his masculinity, race, gender, and class.

Vanessa K. Valdés' Diasporic Blackness is a vital study of the life Schomburg lived, a testament to the contributions of Afro-Latinx people that influenced him to become a bibliophile. The book centers Schomburg's Afro-Latinx identity, heritage, and lineage. Such a work builds on the established field of Latin-American Studies and uniquely foregrounds Afro-Latin American history that is distinct and contributes to the larger Africana Studies lexicon. 